\title{
A New Species of Philautus (Amphibia, Anura, Rhacophoridae) from the Lowland of Sarawak, Western Borneo
}

\author{
$\operatorname{AUTHOR}(S)$ :
}

Matsui, Masafumi

\section{CITATION:}

Matsui, Masafumi. A New Species of Philautus (Amphibia, Anura, Rhacophoridae) from the Lowland of Sarawak, Western Borneo. Zoological Science 2009, 26(6): 437-442

\author{
ISSUE DATE: \\ 2009-06 \\ URL: \\ http://hdl.handle.net/2433/216889 \\ RIGHT: \\ (C) 2009 Zoological Society of Japan
}




\title{
A New Species of Philautus (Amphibia, Anura, Rhacophoridae) from the Lowland of Sarawak, Western Borneo
}

\author{
Masafumi Matsui ${ }^{\star}$ \\ Graduate School of Human and Environmental Studies, Kyoto University, \\ Sakyo-ku, Kyoto 606-8501, Japan
}

\begin{abstract}
A new species in the rhacophorid genus Philautus is described on the basis of five male specimens collected from the Matang Range, a herpetologically well-surveyed area of the lowland of Sarawak, western Borneo. The species possesses a cutaneus pectoris muscle but lacks vomerine teeth, and is assigned to the aurifasciatus group of Philautus. It is superficially similar to some other species of the same group, but can be differentiated from them by a combination of several morphological characters, including lack of a nuptial pad and lingual papilla, and more significantly, by a distinct advertisement call. This discovery underscores the immediate necessity for detailed surveys in the already well-explored lowlands of Borneo.
\end{abstract}

Key words: acoustics, taxonomy, systematics, Borneo, Southeast Asia

\section{INTRODUCTION}

The rhacophorid genus Philautus Gistel, 1848, occurs widely in Southeast and South Asia, from southern China, the Philippines, the Greater Sunda Islands through Thailand and Myanmar to India and Sri Lanka (Frost, 2008). The genus consists of small-sized treefrogs that inhabit bushes and trees and typically develop directly from eggs to metamorphosed young without a free-swimming larval period (Matsui and Orlov, 2004). The genus is large, with about 145 species, and accounts for about half of the family Rhacophoridae (Frost, 2008).

Because of this high species diversity, the infrageneric classification of Philautus has been controversial. Dubois (1987) divided the genus into three distinct subgenera (Gorhixalus Dubois, 1987, endemic to Borneo; Kirtixalus Dubois, 1987, from Sri Lanka and India; and Philautus, including most of the remaining species from Southeast Asia), but Bossuyt and Dubois (2001) later transferred the Indian species to the subgenus Philautus. The results of recent molecular analyses (e.g., Meegaskumbura et al., 2002; Li et al., 2008), however, indicated only remote relationships between the South Asian and Southeast Asian members, supporting Dubois' (1987) earlier idea. Thus, it seems safe to consider members of Philautus from the two major regions separately.

Because some species of Southeast Asian Philautus (sensu stricto) are very similar to each other in morphology, their classification has been seriously confused (e.g., Inger, 1966). Dring (1987) attempted to separate intra- and interspecific variation in this genus, which had been very confusing, imposing serious difficulties in identifying specimens, and designated five species groups among Thai, Philippine,

\footnotetext{
* Corresponding author. Phone: +81-75-753-6846; Fax : +81-75-753-6846; E-mail: fumi@zoo.zool.kyoto-u.ac.jp
}

Bornean, and Javanese Philautus. Nine species in four groups were then known from Borneo, but six additional species have since been described (Inger, 1989; Inger et al., 1995; Inger and Stuebing, 1996; Malkmus and Riede, 1996; Stuebing and Wong, 2000), and other, cryptic species seem to be present on this island (Matsui, unpublished data). During a survey of western Sarawak, northwestern Borneo, between 1989 and 1994, I collected specimens of a Philautus from Gunung (Mount) Serapi in the Matang Range, where intensive herpetological collecting has been conducted for more than 150 years. The call of this species is distinctly different from the calls of Southeast Asian Philautus reported to date (Dring, 1987; Malkmus and Riede, 1996; Malkmus et al., 2002). This species is also different morphologically from all known congeners in the region, and thus I describe it as a new species.

\section{MATERIALS AND METHODS}

I conducted fieldwork at Gunung Serapi, Matang Range, suburbs of Kuching, Sarawak, between 1990 and 1994, and in 2008 Most of the Matang Range is now protected as Kubah National Park (Das et al., 2007). In the field, I recorded calls using a cassette tape recorder (Sony TC-D5) with an external microphone (Sony ECM23). After collecting specimens, I took tissue samples for later biochemical analysis, fixed them in $10 \%$ formalin, later preserved them in $70 \%$ ethanol, and stored them at the Graduate School of Human and Environmental Studies, Kyoto University (KUHE), and Sarawak Museum (SM).

From preserved specimens, I took the following 21 body measurements (Table 1), mainly following Matsui (1984), to the nearest $0.1 \mathrm{~mm}$ with dial calipers under a binocular dissecting microscope: snout-vent length (SVL); head length (HL) from tip of snout to hind border of angle of jaw, not measured parallel with the median line; snout length (SL); nostril-eye distance (N-EL); eye length (EL); tympanum-eye distance (T-EL); tympanum diameter (TD); head width (HW); internarial distance (IND); interorbital distance (IOD); upper eyelid width (UEW); lower arm length (LAL) from axilla to tip of third finger; first finger length (1FL) from distal end of inner palmar tubercle to tip of first finger; inner palmer tubercle length (IPTL); tibia 
Table 1. Measurements of 21 characters from five males of Philautus davidlabangi. SVL (mean $\pm 1 S D$, in millimeters) and medians of ratios $(R)$ of other characters to SVL, followed by ranges in parenthesis.

\begin{tabular}{ccccccc}
\hline SVL & RHL & RSL & RN-EL & REL & RT-EL & RTD \\
\hline $20.4 \pm 0.30$ & 41.3 & 16.6 & 10.1 & 18.3 & 1.7 & 5.9 \\
$(19.9-20.6)$ & $(40.0-43.1)$ & $(15.8-17.3)$ & $(8.3-10.8)$ & $(16.8-18.6)$ & $(1.0-2.5)$ & $(5.54-6.9)$ \\
\hline RHW & RIND & RIOD & RUEW & RLAL & R1FL & RIPTL \\
\hline 39.7 & 10.9 & 11.7 & 11.9 & 51.0 & 7.7 & 4.5 \\
$(37.5-40.8)$ & $(10.5-11.6)$ & $(10.8-12.2)$ & $(10.4-12.4)$ & $(50.0-51.4)$ & $(7.2-8.5)$ & $(4.0-5.6)$ \\
\hline RTL & RFL & RHLL & RIMTL & R1TL & R3FDW & R4TDW \\
\hline 54.0 & 44.3 & 169.6 & 4.7 & 8.4 & 6.0 & 5.8 \\
$(51.5-56.4)$ & $(42.1-45.1)$ & $(160.8-175.3)$ & $(4.1-4.8)$ & $(7.0-8.8)$ & $(4.9-6.4)$ & $(4.2-6.7)$ \\
\hline
\end{tabular}

length (TL); foot length (FL) from proximal end of inner metatarsal tubercle to tip of fourth toe; hindlimb length (HLL); inner metatarsal tubercle length (IMTL); first toe length (1TL) from distal end of inner metatarsal tubercle to tip of first toe; third finger disk diameter (3FDW); fourth toe disk diameter (4TDW). I used the style of webbing formula given by Savage (1975).

For comparisons, I examined some type specimens of species of Philautus from Borneo and adjacent regions of Southeast Asia stored at the Natural History Museum, London (BM), and the Muséum National d'Histoire Naturelle, Paris (MNHNP). I analyzed recorded calls with the computer programs SoundEdit Vers. 2 and SoundEdit Pro (MacroMind-Paracomp, Inc.) run on a Macintosh computer, as described elsewhere (Matsui, 1997).

\section{SYSTEMATICS}

Philautus davidlabangi sp. nov.

(Fig. 1)

\section{Holotype}

KUHE 19594, an adult male from Gunung Serapi, Matang Range, in the suburbs of Kuching, Sarawak $\left(01^{\circ} 36^{\prime} \mathrm{N}, 110^{\circ} 11^{\prime} \mathrm{E}\right.$, alt. $330 \mathrm{~m}$ a.s.l.), collected on 24 December 1994 by Masafumi Matsui and Kunio Araya.

\section{Paratypes}

Four adult males: KUHE 19572, SM Da 1.4.8(a), data same as the holotype; KUHE 10688, collected on 22 January 1990 at $165 \mathrm{~m}$ a.s.I., and KUHE 10735, collected on 24 January 1990 at $300 \mathrm{~m}$ a.s.l. by M. Matsui.

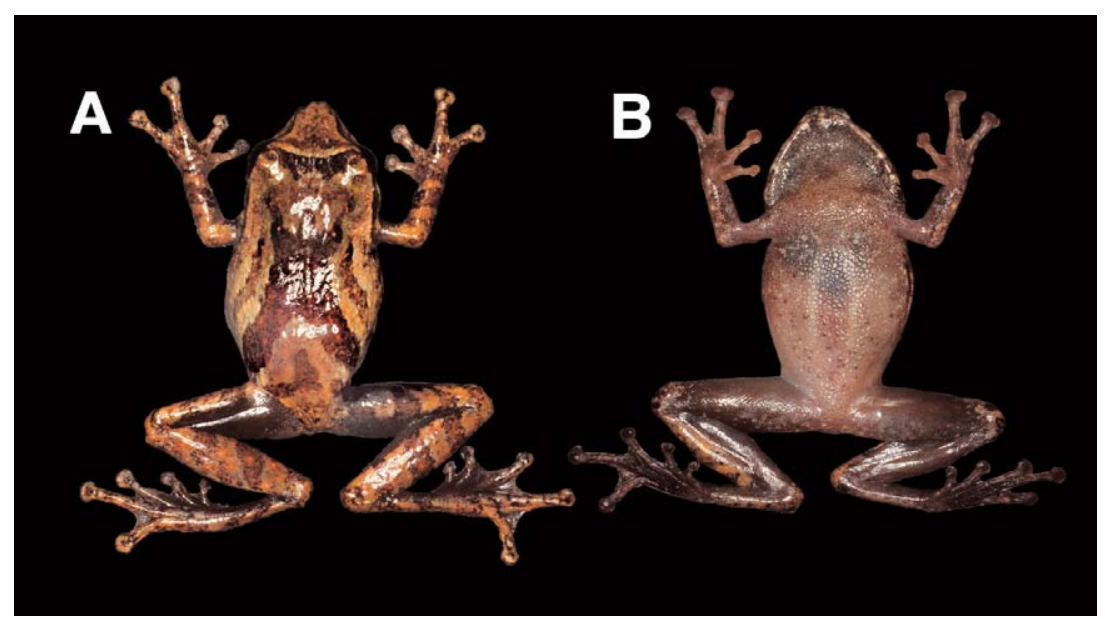

Fig. 1. (A) Dorsal and (B) ventral views of the holotype of Philautus davidlabangi (KUHE 19594). Snout-vent length, $20.6 \mathrm{~mm}$.

\section{Etymology}

The specific name is dedicated to Mr. David Labang, former officer of the Wildlife Department of Sarawak, who always greatly supported my field surveys in Sarawak.

\section{Diagnosis}

A small (male 19.9-20.6 mm in SVL) Philautus of the aurifasciatus species group, with cutaneus pectoris muscle; fifth toe webbed to the point beyond distal edge of distal subarticular tubercle; anterior face and rear of thigh uniformly reddish brown without marking; similar to $P$. amoenus, $P$. mjobergi, and $P$. petersi in body size, but different from them in lacking lingual papilla and male nuptial pad; smaller than $P$. saueri and $P$. umbra, and larger than $P$. longicrus and $P$. refugii; markedly different acoustically from $P$. amoenus, $P$. mjobergi, $P$. petersi, and $P$. saueri in the combination of many pulses and short note duration in advertisement calls.

\section{Description of holotype (measurements in millimeters)}

Body stocky, snout-vent length 20.6; head (8.6) longer than wide (8.2); snout short (3.6), shorter than eye (3.8), obtusely pointed in outline, rounded in profile, without a rostral cone, projecting slightly; canthus distinct, rounded, slightly constricted behind nostrils; lores oblique, concave; nostril in a raised prominence, closer to tip of snout than to eye; internarial distance (2.4) greater than eye-nostril distance (1.8) and interorbital distance (2.2); latter smaller than upper eyelid width (2.5); pupil horizontal; tympanum distinct, length (1.3) one-third eye diameter, separated from eye by one-third of tympanum diameter (0.4); vomerine teeth absent; lingual papilla absent; a short, longitudinal opening into median subgular vocal sac on both sides of mouth floor.

First finger shorter than second, length of first (1.5, measured from distal edge of inner palmar tubercle) less than half diameter of eye; fourth finger much longer than second; tips of fingers dilated into broad disks, diameter of the disk of first finger (0.7) three-fifths that of third finger (1.2); latter subequal to tympanum; free parts of digits fringed with fleshy ridges; webs between fingers poorly developed at base; subarticular tubercles distinct; distinct inner and two indistinct, elongate outer palmar tubercles; nuptial pad absent.

Hindlimb length (33.9) more than two times length of forelimb (13.1); tibia not long (11.1), heels overlapping when limbs are held at right angles to body; tibiotarsal articulation of adpressed limb reaching between nostril and snout tip; foot (8.7) shorter than tibia; tips of toes expanded into disks slightly smaller than those of fingers (disk diameter of fourth toe 1.0); fifth toe slightly longer than third; webs between toes moderately devel- 
oped, two outer metatarsals not separated with webbing; webbing formula $\mid 1^{3} / 4-21 / 4\|1-21 / 4\| I 1-2 I V 2-1 \mathbf{V}$; fringe of skin along inner edge of first toe; subarticular tubercles distinct; a low, elongated inner metatarsal tubercle, length (1.0) two-thirds length of first toe (1.7); no outer metatarsal tubercle.

Skin above scattered with small, round tubercles; a curved row of larger tubercles scattered on both sides of shoulder from rear of eye to sacrum; sides with irregularly distributed round tubercles; eyelid with several low tubercles; a distinct supratympanic fold from eye to axilla; throat finely and abdomen coarsely granular.

\section{Color}

In life, dorsum light brown, with dark-brown interorbital, canthal, and supratympanic bars; a wide-limbed, darkbrown, X-shaped mark on dorsum from rear of upper eyelids, centered on sacrum, to groin, parallel to a narrower, paler line laterally on flank; limbs barred with dark brown dorsally, uniformly dark reddish brown ventrally; anterior and posterior faces of thigh uniformly dark reddish brown without bars or spots; ventral side grayish white, darker on chin and breast, with scattered punctuation on posterior half of abdomen (Fig. 1).

In preservative, pattern has not obviously changed, though color has generally faded. The dorsal ground coloration has faded to grayish brown, and anterior half of body and hindlimb have become finely dotted ventrally.

\section{Variation}

Snout-vent length (19.9-20.6 mm) varied little in the type series. In three of the paratype individuals, internarial distance was slightly less than interorbital distance, and the latter was slightly wider than upper eyelid in two individuals. Disk of third finger was slightly larger than tympanum in two of the paratypes. The point reached by the tibiotarsal articulation of the adpressed limb was slightly variable; among the paratypes, this point was between nostril and snout tip in one individual, at the nostril in two individuals, and between eye and nostril in one individual. The paratypes were otherwise very similar in body proportions. Two of the paratypes had toe webbing less well developed than the others, with the fifth toe webbed to between distal edge of distal subarticular tubercle and base of disk. Dorsal color was extremely variable, and there were three types. Among the four paratype specimens, one had the dark, widelimbed, X-shaped mark like the holotype, two had a pair of dark dorsolateral bands not meeting medially, and one had dark spots only on shoulder and flank. The throat was heavily pigmented in two individuals, and the abdomen was spotted dark in one.

\section{Calls}

Calls were recorded at the type locality on 23 and 25 January 1990. The surface temperature of the leaves where frogs perched at the time of recording was $23.5-24.2^{\circ} \mathrm{C}$. The call consists of a single pulsed note lasting 50-60 ms (Fig. 2) and emitted at a long interval of $1810-2570 \mathrm{~ms}$. A note includes 13-15 pulses, and the pulse repetition rate ranges from 250-300 pulses/s. The dominant frequency is spread over the 2875-2960 hz range, and harmonic frequencies

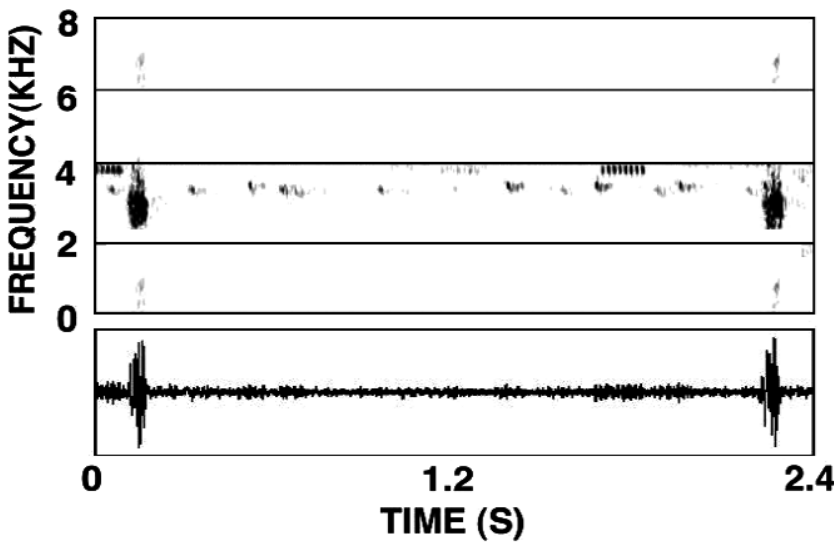

Fig. 2. Sonagram (top) and waveform (bottom) of an advertisement call of Philautus davidlabangi.

are not clear. The call lacks frequency modulation, but intensity modulation is present.

\section{Comparisons}

The presence of the cutaneus pectoris muscle places $P$. davidlabangi in the aurifasciatus species group among the four species groups of Philautus from Borneo, and distinguishes the species from the hosii (as hosei), vermiculatus, and tectus groups, which lack the muscle (Dring, 1987; Inger and Stuebing, 1996). Among the aurifasciatus group from Borneo, P. davidlabangi, with a male SVL of 19.9-20.6 $\mathrm{mm}$, overlaps in male body size with $P$. amoenus Smith, 1931 (18.1-24.2 mm: Malkmus and Riede, 1996), $P$. mjobergi Smith, 1925 (18.7-24.1 mm: Dring, 1987), and $P$. petersi (Boulenger, 1900) (including $P$. castanomerus [Boulenger, 1905] and $P$. larutensis [Boulenger, 1900], 20.2-26.8 mm: Dring, 1987; Malkmus and Riede, 1996), but is smaller than $P$. saueri Malkmus and Riede, 1996 (21.4 mm: Malkmus and Riede, 1996) and $P$. umbra Dring, 1987 (24.7-35.1 mm: Dring, 1987), and larger than $P$. longicrus (Boulenger, 1894) (14.8-19.2 mm: Dring, 1987) and $P$. refugii Inger and Stuebing, 1996 (15.3-18.0 mm: Inger and Stuebing, 1996).

Philautus davidlabangi differs from $P$. amoenus, $P$. mjobergi, $P$. petersi, and $P$. umbra in constantly lacking a lingual papilla and nuptial pad. In addition, $P$. davidlabangi differs from $P$. amoenus, $P$. mjobergi, and $P$. petersi in having a relatively narrower head $(37.5-40.8 \%$ SVL vs. $39.5-46.7 \%$, 39.4-48.4\%, and 40.9-44.4\% SVL, respectively: Malkmus and Riede, 1996; Dring, 1987). Philautus davidlabangi also differs from $P$. petersi in having a shorter tibia (51.5-56.3\% SVL vs. $52.8-62.8 \%$ SVL in $P$. petersi: Dring, 1987). Philautus saueri has a deeper, relatively wider snout (N-EL/IND ratio 73.1\%: Malkmus and Riede, 1996) than $P$. davidlabangi (75.5-102.8\%), and has black reticulation on white to whitish grey sides of the body and rear of the thigh (Malkmus et al., 2002; vs. no such marking in $P$. davidlabangi). Philautus umbra is almost uniformly black dorsally and ventrally, with a rudimentary nuptial pad and poor toe webbing, with the fifth toe webbed to the middle or base of the distal subarticular tubercle, or not so far (vs. neither dorsum nor ventrum uniformly black, lacking nuptial 
pad, and fifth toe webbed to a point beyond the distal subarticular tubercle in $P$. davidlabangi). Philautus davidlabangi resembles the two smaller species in lacking a lingual papilla, and in having the fifth toe webbed beyond the distal subarticular tubercle. However, a nuptial pad is present in $P$. longicrus and $P$. refugii (vs. absent in $P$. davidlabangi). Philautus refugii has the thigh with a barred anterior surface (vs. unmarked in $P$. davidlabangi), and $P$. longicrus has the tibia relatively longer (59.0-64.4\% SVL: Dring, 1987) than in P. davidlabangi (51.5-56.4\% SVL).

Among the species of the aurifasciatus group from outside Borneo, P. aurifasciatus (Schlegel, 1837) from Java (including $P$. robinsoni [Annandale, 1917], male SVL 18.9$20.6 \mathrm{~mm}$ : Dring, 1987, or 15-25 mm: Iskandar, 1998), and $P$ acutirostris (Peters, 1867) (including $P$. basilanensis Taylor, 1922, and $P$. woodi Stejneger, 1905, 20.8-22.4 mm: Dring, 1987, or16.1-22.7 mm: Brown and Alcala, 1994), $P$. leitensis (Boulenger, 1897) (19.5 mm: Inger, 1954 or 19.2$21.9 \mathrm{~mm}$ : Brown and Alcala, 1994) and P. schmackeri (Boettger, 1892) (including P. mindorensis [Boulenger, 1897], ca. $20 \mathrm{~mm}$ : Inger, 1954, or 19.0-21.5 mm: Brown and Alcala, 1994), all from the Philippines, overlap $P$. davidlabangi in male body size. Only $P$. parvulus (Boulenger, 1893) (18.0-19.6 mm: Taylor, 1962) from Thailand and Peninsular Malaysia is definitely smaller than $P$. davidlabangi.

Like $P$. davidlabangi, Javanese $P$. aurifasciatus lacks lingual papilla but has a nuptial pad and relatively wider snout (N-EL/IND ratio 72.3-89.8\%, median 79.2\%: Dring, 1987 ) than $P$. davidlabangi (75.5-102.8\%, median 93.5\%). Unlike $P$. davidlabangi, males of the Philippine species have either a small to moderate-sized ( $P$. acutirostris and $P$. leitensis) or large ( $P$. schmackeri) nuptial pad. Further, $P$. acutirostris has a sharply pointed snout, often with a palecolored projection at tip, angular canthus, fifth toe webbed only to the distal tubercle, and usually vomerine teeth (vs. snout not modified, canthus rounded, toe webbing better developed, and no vomerine teeth in $P$. davidlabangi), and $P$. leitensis has a larger tympanum relative to eye length (usually TD/EL ratio $>35 \%$ : Brown and Alcala, 1994) than $P$. davidlabangi (30-35\%). Philautus schmackeri has the dorsum heavily shagreened (vs. smooth with low tubercles in $P$. davidlabangi).

Differences are more pronounced in the call than in morphology. Detailed call characteristics have been reported for $P$. amoenus, $P$. mjobergi, $P$. petersi, and $P$. saueri among the Bornean species of the aurifasciatus group (Dring, 1987; Malkmus and Riede, 1996). Except for P. petersi, the calls of these species have a complex structure of pulses, pulse trains (=notes), call groups (=calls) and call series, unlike the call of $P$. davidlabangi. Although the call of $P$. peters $i$ consists of a single note like that of $P$. davidlabangi, it is much longer and includes many more pulses.

The number of pulses included and duration of a note are respectively reported to be 1-4 pulses and $110 \mathrm{~ms}$ in $P$. amoenus, 2-8 pulses and 20-105 ms in P. mjobergi, 16-56 pulses and 1180-1500 ms in $P$. petersi, and 2-4 pulses and 30-40 ms in P. saueri (Dring, 1987; Malkmus and Riede, 1996; Malkmus et al., 2002). All these values are very different from those found in a note of $P$. davidlabangi (13-15 pulses and 50-60 ms), although the differences may have been slightly affected by differences in the temperature at the time of recording. According to Dring (1987), P. longicrus and $P$. umbra have rattling calls similar to that of $P$. mjobergi, and which are thus quite different from the call of $P$. davidlabangi. The extralimital species $P$. aurifasciatus from Java and $P$. parvulus from Thailand also differ from $P$. davidlabangi in call characteristics, such as having a higher frequency (Heyer, 1971; Dring, 1987; Matsui, unpublished data).

\section{Range}

Known only from the type locality, Gunung Serapi, Matang Range, suburbs of Kuching City, State of Sarawak, East Malaysia.

\section{Natural history}

The types of Philautus davidlabangi were found perching on leaves of trees (0.6-3 $\mathrm{m}$ above the ground) along a road in a mixed dipterocarp forest. In the late December and January, the males were actively calling at night. Calling activities were less active and from higher portion of trees in November, and calls were seldom heard in August. No females or eggs were found near the calling males. Sometimes the species was syntopic with P. tectus Dring, 1987, which, however, was normally found among ferns and not in tall trees.

\section{DISCUSSION}

In splitting Southeast Asian Philautus into five species groups, Dring (1987) reported call characteristics of the hosii, vermiculatus, and aurifasciatus groups. According to him, calls of the aurifasciatus group are generally pulsed, poorly tuned, and not frequency modulated. These traits, typical of $P$. petersi and $P$. mjobergi, apply to the call of $P$. davidlabangi, although the calls of these species are completely different to the human ear. Call characteristics as defined by Dring (1987), however, actually seem not always to be species-group specific. Of the two species placed morphologically in the vermiculatus group, $P$. aurantium Inger, 1989 , has a well-tuned call that is quite different from the calls of $P$. vermiculatus (Boulenger, 1900) and $P$. kerangae Dring, 1987, whereas $P$. bunitus Inger, Stuebing, and Tan, 1995, has a call closely resembling the calls of $P$. vermiculatus and $P$. kerangae in structure (Malkmus et al., 2002) and to the human ear (Matsui, unpublished data).

Because of a paucity of distinct morphological differences, some populations of Philautus, once recognized as distinct localized species, are now synonymized with wide ranging species (e.g., $P$. castanomerus and $P$. larutensis now synonymized with $P$. petersi). However, recent discoveries of many cryptic species in various lineages of frogs (e.g., Leong et al., 2003; Matsui, 1997, 2006; Matsui and Nabhitabhata, 2006; Matsui et al., 1999, 2005, 2007a, b; Ohler and Delorme, 2006; Shimada et al., 2008; Toda et al., 1998) suggest that each of these populations may actually represent a good species. In solving these problems, acoustic analyses would play a great role, but recordings of calls in the field are not always easy. By contrast, molecular analyses (e.g., Wilkinson et al., 2002) are easier, and would play the same role in elucidating the actual taxonomic diversity within each of the wide-ranging Philautus species.

The Matang range, including the type locality of $P$. 
davidlabangi, is located close $(<25 \mathrm{~km})$ to the city of Kuching, where Sarawak Museum was established by Rajah Charles Brooke in 1888 with the encouragement of Alfred Russell Wallace. Because of this advantage of the terrain, the Matang range has been well surveyed herpetologically since the 1830s (Das et al., 2007), and is the type locality of many amphibian species, including Leptolalax gracilis (Günther, 1872), Ansonia leptopus (Günther, 1872), Hylarana signata (Günther, 1872), Meristogenys jerboa (Günther, 1872), Pelophryne guentheri (Boulenger, 1882), Ansonia minuta Inger, 1960, and Ichthyophis biangularis Taylor, 1965. The range is only less than $1000 \mathrm{~m}$ in altitude at the peak, but nevertheless, the amphibian fauna as recorded by Das et al. (2007) comprises as many as 53 anuran and two caecilian species ( $P$. davidlabangi is listed and figured as Philautus sp.). This number, however, is still an underestimate, because Das et al. (2007) overlooked some old records, and at least several more species of Philautus ( $P$. kerangae and $P$. petersi, and possibly $P$. aurantium) occur in the range (Matsui, unpublished data).

Anyhow, this kind of lowlands would surely embrace additional species, as exemplified by the recent discovery of Rhacophorus gadingensis Das and Haas, 2005 from Gunung Gading, not far from the Matang range (Das and Haas, 2005). A vast range of Borneo remains to be surveyed herpetologically, and intensive explorations of the biodiversity are surely required. However, detailed surveys in the well-explored lowlands also have an immediate necessity. A broad area of the Matang Range is now protected as Kubah National Park, but the fringe borders are rapidly being developed, and an anticipated increase in tourism in the park might cause environmental deterioration. To prevent population declines in many valuable species, further environmental conservation measures are necessary.

\section{ACKNOWLEDGMENTS}

The Socio-Economic Research Unit of Malaysia and the State Government of Sarawak kindly provided permission to conduct fieldwork in Sarawak between 1989 and 1994. The Forest Department, Sarawak provided all the facilities for conducting research. L.H. Seng, A. H. Kassim, N.-S. Wong, J. J. Kendawong, A. H. Abang, and D. Labang are acknowledged for help on field trips. K. Araya helped me in collecting valuable material, and T. Hikida accompanied me in the field. For the fieldwork in 2008, the Economic Planning Unit of the Prime Minister's Department and The Forest Department, Sarawak, kindly issued research passes (40/200/19/ 2285 and NPW.907.4.2(III)-68, respectively). I am grateful to Datu Haji Len Talif Salleh, Director of Forest Sarawak, L. Chong of the Sarawak Diversity Center, and R. Mohidin and his staff at Kubah National Park for their help, and K. Nishikawa for field and laboratory assistance. I thank C. McCarthy and B. T. Clarke (BM), and A. Dubois and A. Ohler (MNHNP) for allowing me to examine specimens under their care. Field trips were made possible by grants under The Monbusho International Scientific Research Program (Field Research, Nos. 01041051, 02041051, 03041044, 04041068) and grants from The Monbusho through the Japanese Society for the Promotion of Science (JSPS; Field Research, No. 20405013).

\section{REFERENCES}

Bossuyt F, Dubois A (2001) A review of the frog genus Philautus Gistel, 1848 (Amphibia, Anura, Raninae, Rhacophorinae). Zeylanica 6: 1-112
Brown WC, Alcala AC (1994) Philippine frogs of the family Rhacophoridae. Proc Calif Acad Sci 48: 185-220

Das I, Haas A (2005) A new species of Rhacophorus (Anura: Rhacophoridae) from Gunung Gading, Sarawak. Raffles Bull Zool 53: 257-263

Das I, Jankowski A, Makmor MIB, Haas A (2007) Species diversity, elevational distribution and reproductive modes in an amphibian community at the Matang Range, Sarawak (Borneo). Mitt Hamb Zool Mus Inst 104: 141-174

Dring JCM (1987) Bornean treefrogs of the genus Philautus (Rhacophoridae). Amphibia-Reptilia 8: 19-47

Dubois A (1987 [1986]) Miscellanea taxinomica [sic] batrachologica (I). Alytes 5: 7-95

Frost DR (2008) Amphibian species of the world: an online reference, Version 5.2 (15 July, 2008). American Museum of Natural History, New York, Electronic database accessible at http:// research.amnh.org/herpetology/amphibia/index.html

Heyer WR (1971) Mating calls of some frogs from Thailand. Fieldiana Zool 58: 61-82

Inger RF (1954) Systematics and zoogeography of Philippine Amphibia. Fieldiana Zool 33: 181-531

Inger RF (1966) The systematics and zoogeography of the Amphibia of Borneo. Fieldiana Zool 52: 1-402

Inger RF (1989) Four new species of frogs from Borneo. Malay Nat J 42: 229-243

Inger RF, Stuebing RB (1996) Two new species of frogs from southeastern Sarawak. Raffles Bull Zool 44: 543-549

Inger RF, Stuebing RB, Tan FL (1995) New species and new records of anurans from Borneo. Raffles Bull Zool 43: 115-131

Iskandar DT (1998) The Amphiibians of Java and Bali. Puslitbang Biologi, LIPI, Bogor

Leong TM, Matsui M, Yong HS, Hamid AA (2003) Revalidation of Rana latelimaculata Barbour et Noble, 1916 from synonymy of Rana baramica Boettger, 1901. Curr Herpetol 22: 17-27

Li JT, Che J, Bain RH, Zhao EM, Zhang YP (2008) Molecular phylogeny of Rhacophoridae (Anura): A framework of taxonomic reassignment of species within the genera Aquixalus, Chiromantis, Rhacophorus, and Philautus. Mol Phylogenet Evol 48: 302-312

Malkmus R, Riede K (1996) Die Baumfrösche der Gattung Philautus vom Mount Kinabalu - Teil I: Überblick und die aurifasciatusgruppe mit Beschreibung einer neuen Art (Philautus saueri $\mathrm{n}$. sp.). Sauria 18: 27-37

Malkmus R, Manthey U, Vogel G, Hoffman P, Kosuch J (2002) Amphibians and Reptiles of Mount Kinabalu (North Borneo). ARG Gantner Verlag Kommanditgesellschaft, Ruggell

Matsui M (1984) Morphometric variation analyses and revision of the Japanese toads (Genus Bufo, Bufonidae). Contrib Biol Lab Kyoto Univ 26: 209-428

Matsui M (1997) Call characteristics of Malaysian Leptolalax with a description of two new species (Anura: Pelobatidae). Copeia 1997: 158-165

Matsui M (2006) Three new species of Leptolalax from Thailand (Amphibia, Anura, Megophryidae). Zool Sci 23: 821-830

Matsui M, Nabhitabhata J (2006) A new species of Amolops from Thailand (Amphibia, Anura, Ranidae). Zool Sci 23: 727-732

Matsui M, Orlov N (2004) A new species of Chirixalus from Vietnam (Anura: Rhacophoridae). Zool Sci 21: 671-676

Matsui M, Nabhitabhata J, Panha S (1999) On Leptobrachium from Thailand with a description of a new species (Anura: Pelobatidae). Jpn J Herpetol 18: 19-29

Matsui $M$, Ito $H$, Shimada $T$, Ota $H$, Saidapur SK, Khonsue W, Tanaka-Ueno T, Wu GF (2005) Taxonomic relationships within the Pan-Oriental narrow-mouth toad Microhyla ornata as revealed by mtDNA analysis (Amphibia, Anura, Microhylidae). Zool Sci 22: 489-495

Matsui M, Maryati M, Shimada T, Sudin A (2007a) Resurrection of 
Staurois parvus from S. tuberilinguis from Borneo (Amphibia, Ranidae). Zool Sci 24: 101-106

Matsui M, Toda M, Ota $\mathrm{H}$ (2007b) A new species of frog allied to Fejervarya limnocharis from the Southern Ryukyus, Japan (Amphibia: Ranidae). Curr Herpetol 26: 65-79

Meegaskumbura M, Bossuyt F, Pethiyagoda R, ManamendraArachchi K, Bahir M, Milinkovitch MC, Schneider CJ (2002) Sri Lanka: an amphibian hotspot. Science 298: 379

Ohler A, Delorme M (2006) Well known does not mean well studied: morphological and molecular support for existence of sibling species in the Javanese gliding frog Rhacophorus reinwardtii (Amphibia, Anura). CR Biol 329: 86-97

Savage JM (1975) Systematics and distribution of the Mexican and Central American stream frogs related to Eleutherodactylus rugulosus. Copeia 1975: 254-306

Shimada T, Matsui M, Yambun P, Lakim M, Maryati M (2008) The utility of mitochondrial and nuclear DNA in detecting a cryptic taxon in Meristogenys amoropalamus (Amphibia, Ranidae). Zootaxa 1843: 24-34
Stuebing RB, Wong A (2000) A new species of frog, Philautus erythrophthalmus (Rhacophoridae) from southwestern Sabah, Malaysia. Raffles Bull Zool 48: 293-296

Taylor EH (1962) The amphibian fauna of Thailand. Univ Kansas Sci Bull 43: 265-599

Toda M, Matsui M, Nishida M, Ota H (1998) Genetic divergence among Southeast and East Asian populations of Rana limnocharis (Amphibia: Anura), with special reference to sympatric cryptic species in Java. Zool Sci 15: 607-613

Wilkinson JA, Drewes RC, Tatum OL (2002) A molecular phylogenetic analysis of the family Rhacophoridae with an emphasis on the Asian and African genera. Mol Phylogenet Evol 24: 265273

(Received January 3, 2009 / Accepted April 14, 2009) 